\title{
Urgensi Pengesahan RUU PKS sebagai Upaya Perlindungan Hukum Bagi Korban Revenge Porn
}

\author{
Cindy Kang
}

Universitas Internasional Batam, cindykang06@gmail.com

\begin{abstract}
Based on data obtained from the Annual Records of the National Commission on Women, the percentage of violence against women has increased by $792 \%$ in the past 12 years. In addition, cases of Online Gender Based Violence (OGBV) have increased $300 \%$ and the most cases are revenge porn cases. This proves that women are one of the most vulnerable subjects to become victims of violence, and violence against women is not only carried out in the real world but also in cyberspace. One of the most common $O G B V$ cases is revenge porn, where a perpetrator threatens to spread pornographic content belonging to the victim online without the victim's consent with the potential to damage the victim's reputation. The absence of regulations governing revenge porn makes it difficult for victims to get legal protection. The existence of the Draft Law on the Elimination of Sexual Violence (RUU PKS) which specifically regulates the types of sexual violence has given rise to hope for victims in seeking justice. The purpose of this study is to examine the urgency of the ratification of the RUU PKS regardless of the pros and cons circulating in society in providing legal protection for the victims. This study uses a normative legal research method that emphasized data obtained indirectly, such as legal materials. The results of this study indicate that the existence of laws and regulations such as the Electronic Transaction and Information Act, the Pornography Law, as well as provisions in the Criminal Code are considered insufficient to provide legal protection for the victims. Therefore, it is necessary to ratify the RUU PKS as a legal umbrella to provide protection for the victims.
\end{abstract}

Key Words: Legal Protection; Sexual Violence; Revenge Porn

\begin{abstract}
Abstrak
Berdasarkan data yang diperoleh dari Catatan Tahunan Komisi Nasional Perempuan (Komnas Perempuan), persentase kekerasan terhadap perempuan telah mengalami peningkatan sebesar $792 \%$ dalam kurun waktu 12 tahun. Selain itu, kasus Kekerasan Berbasis Gender Online (KBGO) telah mengalami peningkatan sebesar $300 \%$ dan kasus terbanyak adalah kasus revenge porn. Hal ini membuktikan bahwa wanita merupakan salah satu subjek yang sangat rentan menjadi korban kekerasan, dan kekerasan terhadap wanita tidak hanya dilakukan dalam dunia nyata namun juga dunia maya. Salah satu KBGO yang marak terjadi adalah kasus revenge porn, dimana seorang pelaku mengancam untuk menyebarkan konten pornografi milik korban secara online tanpa sepengetahuan atau persetujuan korban dengan potensi merusak reputasi milik korban. Belum adanya regulasi khusus yang mengatur mengenai revenge porn membuat korban kesulitan mendapat perlindungan hukum. Adanya Rancangan Undang-Undang

Penghapusan Kekerasan Seksual (RUU PKS) yang mengatur secara spesifik mengenai jenisjenis kekerasan seksual telah melahirkan harapan bagi para korban dalam mencari keadilan. Tujuan dari penelitian ini adalah mengkaji urgensi pengesahan RUU PKS terlepas dari pro dan kontra yang beredar dalam masyarakat dalam memberikan perlindungan hukum bagi para korban revenge porn. Penelitian ini menggunakan metode penelitian hukum normatif yang
\end{abstract}

Jurnal YUSTIKA Media Hukum dan Keadilan Fakultas Hukum Universitas Surabaya Vol. 24 No. O1, Juli 2021 E-ISSN: 2655-7479 
mengedepankan pada data yang diperoleh secara tidak langsung, seperti bahan-bahan hukum. Hasil dari penelitian ini menunjukan bahwa adanya peraturan perundang-undangan seperti Undang-Undang Informasi Transaksi Elektronik (UU ITE), Undang-Undang Pornografi, serta ketentuan dalam Kitab Undang-Undang Hukum Pidana (KUHP) dinilai tidak cukup memberikan perlindungan hukum bagi korban revenge porn. Maka, dibutuhkan pengesahan RUU PKS sebagai payung hukum untuk memberikan perlindungan bagi para korban.

Kata Kunci: Perlindungan Hukum; Kekerasan Seksual; Revenge Porn

\section{Pendahuluan}

Pada tahun 2020, Komisi Nasional Perempuan (Komnas Perempuan) mencatat bahwa terdapat 299.911 kasus kekerasan terhadap wanita di Indonesia (Riana \& Amirullah, 2021). Jenis kasus yang tercatat pada Komnas Perempuan berupa kasus kekerasan terhadap istri (KTI), kekerasan dalam pacaran, kekerasan terhadap anak perempuan, serta kekerasan lain yang dilakukan oleh mantan pacar, mantan suami, dan kekerasan terhadap asisten rumah tangga. Kekerasan terhadap wanita dapat terjadi dalam banyak bentuk, yaitu kekerasan fisik, kekerasan seksual, kekerasan psikis, serta kekerasan ekonomi. Data tersebut menunjukkan bahwa wanita merupakan salah satu subjek yang sangat rentan menjadi korban kekerasan.

Selain itu, teknologi yang semakin canggih di abad ke-21 ini merupakan salah satu faktor penyebab maraknya kekerasan terhadap wanita. Kemajuan teknologi tidak hanya memberikan dampak positif namun juga memberikan dampak negatif. Salah satu dampak positif dari kemajuan teknologi adalah memungkinkan masyarakat untuk saling berinteraksi dengan mudah melalui media sosial, namun di sisi lain, interaksi di media sosial ini memberikan dampak negatif karena maraknya Kekerasan Berbasis Gender Online (KBGO) yang terjadi di internet (Ramailis, 2020).

Kekerasan Berbasis Gender merupakan kekerasan yang dilakukan atas dasar gender atau kondisi seksualitas yang dapat mengakibatkan bahaya secara fisik, psikis, maupun seksual dengan cara memaksa dan merampas kemerdekaan seseorang. KBGO semakin marak terjadi, terutama pada masa pandemi COVID-19 (The Conversation, 2020). Situasi pandemi COVID-19 yang terjadi sejak tahun 2020 mengharuskan banyak masyarakat untuk tinggal di rumah guna meminimalisir terjadinya penyebaran virus corona. Hal ini mengakibatkan meningkatnya persentase waktu seseorang dalam mengakses internet sebagai kegiatan mengisi waktu atau hiburan setiap harinya.

Jaringan internet yang tidak terbatas mempermudah penyebaran suatu informasi dari satu akun ke akun lainnya, hal ini mengakibatkan banyak tersebarnya konten eksplisit seperti konten pornografi dan konten dewasa lainnya (Christianto, 2020). Tentu hal ini dapat memberi pengaruh yang sangat buruk bagi banyak orang terutama pada anak di bawah umur yang mengakses media sosial tanpa pengawasan orang tua. Banyaknya kejahatan seksual yang terjadi di media sosial mengakibatkan media sosial menjadi tempat yang tidak ramah bagi wanita dan anak di bawah umur.

Berdasarkan data yang diperoleh dari Catatan Tahunan Komnas Perempuan, persentase kekerasan terhadap perempuan telah mengalami peningkatan sebesar $792 \%$ dalam kurun waktu 12 tahun. Selain itu, kasus cyber crime atau KBGO telah mengalami peningkatan sebesar $300 \%$ dan kasus terbanyak adalah kasus revenge porn, yaitu sebanyak 33\% (Komnas Perempuan, 2020). Revenge porn atau pornografi balas dendam adalah suatu tindakan saat seseorang 
Jurnal Yustika

Vol. 24 No. 01, Juli 2021

Halaman | 51

Urgensi Pengesahan RUU PKS sebagai

Upaya

Perlindungan

Hukum Bagi

Korban Revenge

Porn

Cindy Kang mengancam untuk menyebarkan foto/video/dokumentasi pribadi milik seseorang tanpa izin. Yang dimaksud dengan dokumentasi pribadi adalah bahwa foto dan/atau video tersebut bukanlah untuk bahan konsumsi publik. Oleh karena itu, revenge porn termasuk dalam kategori pornografi non-konsensual dan pelanggaran terhadap privasi seseorang. Revenge porn biasanya dilakukan oleh mantan kekasih yang motifnya adalah untuk mempermalukan dan melecehkan korban (Ananda, Praviyanti \& Mertha, 2020).

Fenomena revenge porn ini menimbulkan banyak pendapat di masyarakat. Banyak masyarakat yang masih melakukan victim blaming atau menyalahkan korban atas tersebarnya dokumentasi pribadi tersebut. Hal ini diakibatkan oleh budaya misogini dan seksisme yang terjadi di Indonesia. Pemahaman misogini di masyarakat mengakibatkan wanita dijadikan objek seksual (Ananda, Praviyanti \& Mertha, 2020). Selain itu, masih banyak masyarakat yang berperilaku seksisme, yaitu tindakan merendahkan, menghina, memberikan stereotip dan stigma, serta memperdaya, dan sayangnya perilaku seksisme banyak ditujukan terhadap wanita (Yayasan Pulih, 2020).

Salah satu kasus revenge porn yang cukup membuat heboh di Indonesia adalah tersebarnya video berdurasi 19 detik milik seorang selebriti berinisial GA pada Desember 2020. Pihak kepolisian menetapkan GA sebagai tersangka dan dijerat dengan Pasal 29 UndangUndang Nomor 44 Tahun 2008 tentang Pornografi (UU Pornografi) serta Pasal 45 UndangUndang Nomor 11 Tahun 2008 tentang Informasi dan Transaksi Elektronik (UU ITE) meskipun GA sesungguhnya merupakan korban revenge porn (Voi, 2020). Kasus ini telah dengan jelas memperlihatkan bagaimana kedudukan korban revenge porn di hadapan hukum di Indonesia.

Revenge Porn dapat memberikan dampak yang sangat traumatis bagi korban, terutama dari segi psikologis. Selain itu, kebanyakan korban juga mengalami diskriminasi, mendapatkan stigma negatif, dikucilkan oleh masyarakat, direndahkan dan dilecehkan baik secara online maupun offline. Konten pornografi yang ada di media internet juga sangat cepat tersebar dan kerap meninggalkan jejak digital yang sangat sulit untuk dihilangkan. Berdasarkan data dari Cyber Civil Rights Initiative, 82\% korban revenge porn mengalami kerusakan relasi sosial, dan sebanyak 39\% korban mengalami kehancuran karir (Perangin-angin, Rahayu \& Dwiwarno, 2019).

Mengacu pada data yang diperoleh dari Lembaga Bantuan Hukum Asosiasi Perempuan Indonesia untuk Keadilan (LBH APIK), dari ratusan total kasus yang mereka terima, hanya 10\% yang berhasil diproses hingga jalur pengadilan (Febrianna \& Ayu, 2021). Selain itu, eksistensi dari platform media sosial seperti twitter dan telegram juga membuat penyebaran video revenge porn semakin marak. Dokumentasi foto serta video revenge porn tidak hanya sekadar disebarkan, namun juga diperjual-belikan oleh oknum-oknum di media sosial. Selain itu, korban dari eksploitasi ini tidak hanya menimpa kaum perempuan, namun juga laki-laki, serta anak di bawa umur.

Berdasarkan uraian diatas, dapat disimpulkan bahwa revenge porn merupakan salah satu kejahatan yang melanggar privasi serta memberikan dampak kerugian yang sangat besar bagi korban. Adanya peraturan perundang-undangan seperti UU ITE, UU Pornografi, UndangUndang Nomor 37 Tahun 1999 tentang Hak Asasi Manusia (UU HAM), Undang-Undang Nomor 13 Tahun 2006 tentang Perlindungan Saksi dan Korban, dan ketentuan pidana dalam Kitab Undang-Undang Hukum Pidana (KUHP) serta peraturan perundang-undangan lainnya tidak cukup memberikan perlindungan hukum dan kepastian hukum bagi korban revenge porn. 
Hingga saat ini, belum ada peraturan perundang-undangan yang secara spesifik mengatur ketentuan tentang revenge porn meskipun telah terdapat beberapa kasus revenge porn yang sudah pernah diadili di persidangan sebelumnya. Oleh karena itu, dibutuhkan suatu instrumen hukum yang jelas untuk memberikan perlindungan hukum dan kepastian hukum bagi para korban revenge porn. Rancangan Undang-Undang Penghapusan Kekerasan Seksual (RUU PKS) telah masuk dalam prioritas Program Legislasi Nasional (Prolegnas) Dewan Perwakilan Rakyat Tahun 2021. Hal ini menandakan bahwa pemerintah mulai menyadari pentingnya perlindungan hukum bagi wanita khususnya korban Kekerasan Berbasis Gender Online (KBGO). Pada tahun 2014, Komnas Perempuan menyatakan bahwa Indonesia mengalami darurat kekerasan seksual sehingga RUU PKS sangat dibutuhkan untuk menanggulangi permasalahan tersebut (Siburian, 2020).

RUU PKS dengan rinci telah mengklasifikasikan jenis-jenis kekerasan seksual dalam 9 (sembilan) bentuk, sehingga melengkapi kekosongan hukum terkait kekerasan seksual yang ada di Indonesia. RUU PKS diharapkan dapat menjadi lex spesialis dan menjadi payung hukum bagi kasus-kasus kekerasan seksual, sebagaimana yang dikenal dengan asas penafsiran hukum "lex spesialis derogat lex generalis" yang berarti hukum yang bersifat khusus mengesampingkan hukum yang bersifat umum (Wardadi, Manurung, \& Rais, 2019). Eksistensi dari RUU PKS tentu secara tidak langsung telah melahirkan suatu harapan bagi para korban kekerasan seksual yang mengalami kesulitan dalam memperoleh keadilan, serta bagi para perempuan yang sangat rentan menjadi korban kekerasan seksual (Subarkah \& Tobroni, 2020).

Namun, setelah berkali-kali RUU PKS masuk ke dalam Prolegnas, hingga kini RUU tersebut tidak kunjung disahkan (Subarkah \& Tobroni, 2021). Sebagai negara yang menjunjung tinggi Hak Asasi Manusia (HAM) sebagaimana tercantum dalam Undang-Undang Dasar Negara Republik Indonesia Tahun 1945 (UUD NRI 1945), pemerintah seharusnya menjamin kepastian hukum serta perlindungan hukum bagi para korban revenge porn. Pada dasarnya, RUU PKS berfokus untuk menjaga martabat manusia, serta mengedepankan isu gender dan hak asasi manusia (Mohsi, 2020). RUU PKS berorientasi dan berpihak kepada korban dengan harapan bahwa hak-hak korban kekerasan seksual tidak lagi terabaikan, mengingat bahwa peraturan perundang-undangan yang sudah ada dinilai belum komprehensif dalam menangani kasus kekerasan seksual (KemenPPPA, 2020).

Penelitian terdahulu yang mengkaji tema RUU PKS telah dilakukan oleh Natasya Fila Rais, Gracia Putri Manurung, dan Agnes Kusuma Wardani di tahun 2019 berfokus "menganalisis keberlakuan RKUHP dan RUU PKS dalam mengatur tindak kekerasan seksual" (Rais, Manurung \& Wardani, 2019); oleh Alfianita Atiq Junaelis Subarkah dan Faiq Tobroni di tahun 2021 yang berfokus mengkaji "urgensi pengesahan RUU PKS terhadap instrumen penegakan hak asasi perempuan" (Subarkah \& Tobroni, 2021); Riskyanti Juniver Siburian, di tahun 2020 yang berfokus mengkaji "marital rape sebagai tindak pidana dalam ruupenghapusan kekerasan seksual" (Siburian, 2020); dan oleh M. Mohsi pada tahun 2020 yang "menganalisis perkawinan paksa sebagai tindak pidana kekerasan seksual dalam RRU PKS" (Mohsi, 2020).

Berdasarkan beberapa penelitian terdahulu, maka fokus kajian dalam penelitian ini adalah mengkaji urgensi pengesahan RUU PKS guna memberikan perlindungan hukum bagi korban kekerasan seksual, terutama bagi para korban revenge porn di Indonesia. Selain mengkaji permasalahan tersebut, tujuan penelitian ini juga untuk memberikan literasi hukum kepada 
Jurnal Yustika

Vol. 24 No. 01, Juli 2021

Halaman | 53 Urgensi Pengesahan RUU PKS sebagai Upaya Perlindungan Hukum Bagi Korban Revenge Porn

Cindy Kang masyarakat terkait revenge porn dan untuk memberikan kontribusi keilmuan hukum khusunya terkait revenge porn dan urgensi pengesahan RUU PKS.

\section{Metode Penelitian}

Penulisan artikel ilmiah ini menggunakan metode penelitian normatif, berdasarkan peraturan-peraturan tertulis dan studi kepustakaan yang mengkaji aspek teori, struktur, serta penjelasan hukum. Data yang diperoleh dari penulisan artikel ini merupakan data sekunder yang diperoleh dari studi kepustakaan, peraturan perundang-undangan, jurnal ilmiah, dan putusan pengadilan. Pendekatan yang digunakan dalam penulisan jurnal ini adalah pendekatan perundang-undangan, yaitu dengan menelaah peraturan dan regulasi terkait dengan isu hukum dan kasus revenge porn.

\section{Hasil Penelitian dan Pembahasan}

3.1. Budaya Patriarki, Rape Culture serta kaitannya dengan Revenge Porn di Indonesia

Menurut Komnas Perempuan, terminologi dari Kekerasan Seksual adalah "Perbuatan merendahkan, menghina, menyerang, dan/atau tindakan lainnya, terhadap tubuh yang terkait dengan nafsu perkelaminan, hasrat seksual seseorang, dan/atau fungsi reproduksi secara paksa, bertentangan dengan kehendak seseorang, dan/atau tindakan lain yang menyebabkan seseorang tidak mampu memberikan persetujuan dalam keadaan bebas karena ketimpangan relasi kuasa, relasi gender dan/atau sebab lain, yang berakibat atau dapat berakibat penderitaan atau kesengsaraan secara fisik, psikis, seksual, kerugian secara ekonomi, sosial, budaya, dan/atau politik" (Ika, 2019).

Berdasarkan data dari Sistem Informasi Online Perlindungan Perempuan dan Anak Kementerian Pemberdayaan Perempuan dan Perlindungan Anak Republik Indonesia (Simfoni PPA) tahun 2018, terdapat 12.867 laporan kasus kekerasan, dan diantaranya terdapat 3.328 korban laki-laki dan 10.552 korban perempuan. Oleh karena itu, dapat disimpulkan bahwa korban kekerasan seksual bukan hanya perempuan, namun juga laki-laki. Kekerasan seksual tidak memandang gender dan dapat terjadi pada siapapun dan dimanapun. Selain itu, akibat dari perkembangan teknologi yang semakin pesat, muncullah istilah baru untuk menggambarkan kekerasan terhadap perempuan dalam media sosial, yaitu Kekerasan Berbasis Gender Online (KBGO). Simfoni PPA mencatat bahwa angka kasus KBGO selama pandemi telah naik sebanyak 300\% (LM Psikologi UGM, 2021). Faktor penyebab maraknya kasus kekerasan seksual baik secara online maupun secara offline adalah pemikiran rape culture yang berkembang terjadi di Indonesia.

Rape culture adalah istilah untuk mendeskripsikan suatu kondisi lingkungan yang terkesan menganggap remeh perilaku pelecehan seksual (Arifin, 2019). Berkembangnya rape culture di Indonesia dapat diakibatkan oleh beberapa faktor, seperti kurangnya pendidikan seksual di Indonesia, serta masih kentalnya budaya patriarki di Indonesia. Patriarki merupakan suatu sistem sosial atau budaya yang menempatkan laki-laki sebagai pemegang kuasa dan dominan serta lebih unggul dibandingkan perempuan dalam berbagai aspek.

Sistem patriarki berjalan dari generasi ke generasi dan turun temurun sehingga mengakibatkan laki-laki memonopoli seluruh peran dan bahkan terkadang membuat perempuan berada di posisi yang direndahkan. Secara tidak langsung, budaya patriarki yang berlangsung di Indonesia telah mempengaruhi cara pikir masyarakat. Hal tersebut 
menimbulkan ketimpangan gender dan mengakibatkan konflik yang berujung kepada tindak kekerasan terhadap perempuan (Israpil, 2017).

Jurnal Yustika

Terdapat tingkatan-tingkatan pelecehan dan kekerasan seksual yang sering terjadi namun di sisi lain sering disepelekan. Tingkatan ini disusun dari kekerasan seksual yang paling terberat hingga teringan, yaitu: a.) pemerkosaan, pemerkosaan massal, pembunuhan; b.) paksaan seksual, meraba, mengancam, melepas kondom secara diam-diam; c.) penguntitan, revenge porn (ancaman terhadap seseorang untuk menyebarkan konten pornografi milik pribadi ke dunia maya tanpa sepengetahuan atau persetujuan orang tersebut), catcalling (bentuk pelecehan verbal di ruang publik yang berbau 'pujian' atau 'sapaan' bernuansa seksual), mengirim foto alat kelamin, foto tanpa persetujuan; d.) rape jokes (suatu 'lelucon' yang berisikan bercandaan terkait cerita pemerkosaan), menyalahkan korban, wage gap (kesenjangan upah antar gender), percakapan ruang ganti (pembicaraan yang biasa dilakukan antar teman yang berisi mengenai pengalaman seks dan membuka privasi atau menjelekkan bagian tubuh seseorang), dan lain-lain (Ika, 2019).

Selain itu, menurut Southeast Asia Freedom of Expression Network (SAFEnet), terdapat 8 (delapan) jenis KGBO, yaitu: a.) cyber grooming atau memperdaya seseorang secara daring; b.) cyber harassment atau melecehkan seseorang secara daring; c.) hacking atau meretas akun milik orang lain; d.) illegal content atau penyebaran konten ilegal; e.) infringement of privary atau pelanggaran privasi; f.) malicious distribution atau mengancam untuk menyebarkan foto/video/dokumentasi pribadi milik seseorang yang berpotensi merusak reputasi orang tersebut; g.) online defamation atau mencemarkan nama baik seseorang; dan $\mathrm{h}$.) online recruitment atau rekrutmen secara daring (Safenet Voice, 2020). Meskipun kekerasan dengan jenis-jenis tersebut dilakukan secara online, namun dampak fisik dan psikologis yang dirasakan oleh korban dapat mempengaruhi kehidupan offline. KBGO merupakan salah satu jenis kekerasan yang cukup rumit mengingat bahwa kekerasan ini terjadi di ranah digital.

\subsection{Regulasi terkait Revenge Porn dan Urgensi Pengesahan RUU PKS di Indonesia}

Revenge Porn adalah suatu ancaman terhadap seseorang untuk menyebarkan konten pornografi milik pribadi ke dunia maya tanpa sepengetahuan atau persetujuan orang tersebut, atau dibuat tanpa sepengetahuan orang tersebut dengan potensi merusak reputasi orang tersebut (Oktaviani, 2020). Dalam beberapa kasus, revenge porn dikategorikan sebagai malicious distribution akibat ketidakmampuan korban dalam mengidentifikasi siapa pelaku aslinya (Willihardi, 2020).

Hingga saat ini, belum ada Undang-Undang yang secara spesifik mengatur mengenai revenge porn di Indonesia. Namun, terdapat beberapa peraturan di Indonesia yang mengatur ruang lingkup penyebaran konten pornografi, yaitu “Undang-Undang Nomor 11 Tahun 2008 tentang Informasi dan Transaksi Elektronik" (UU ITE); “Undang-Undang Nomor 44 Tahun 2008 tentang Pornografi" (UU Pornografi); “Undang-Undang Nomor 37 Tahun 1999 tentang Hak Asasi Manusia” (UU HAM); “Undang-Undang Nomor 1 Tahun 1974 tentang Perkawinan” (UU Perkawinan); “Undang-Undang Nomor 23 Tahun 2004 tentang Penghapusan Kekerasan Dalam Rumah Tangga" (UU PKDRT); “Undang-Undang Nomor 13 Tahun 2006 tentang Perlindungan Saksi dan Korban” (UU Perlindungan Saksi dan Korban); dan Ketentuan pidana dalam “Kitab Undang-Undang Hukum Pidana” (KUHP).

Merujuk pada Pasal 1 angka 1 UU Pornografi, disebutkan bahwa definisi dari pornografi adalah "gambar, sketsa, ilustrasi, foto, tulisan, suara, bunyi, gambar bergerak, animasi, kartun,
Vol. 24 No. 01, Juli 2021

Halaman | 54

Urgensi Pengesahan

RUU PKS sebagai Upaya

Perlindungan hukum Bagi

Korban Revenge

Porn

Cindy Kang 
Jurnal Yustika

Vol. 24 No. 01, Juli 2021

Halaman | 55

Urgensi Pengesahan RUU PKS sebagai

Upaya

Perlindungan

Hukum Bagi

Korban Revenge

Porn

Cindy Kang percakapan, gerak tubuh, atau bentuk pesan lainnya melalui berbagai bentuk media komunikasi dan/atau pertunjukan di muka umum, yang memuat kecabulan atau eksploitasi seksual yang melanggar norma kesusilaan dalam masyarakat".

Berkaca pada negara-negara lain seperti Australia dan Inggris yang mengatur revenge porn secara khusus, pemerintah di Australia menyediakan portal khusus untuk menghadapi permasalahan revenge porn, selain itu pemerintah di Inggris juga memiliki regulasi terkait revenge porn dan memberikan sanksi 14 tahun penjara pada pelaku revenge porn (Azizi, 2020). Sedangkan di Indonesia, kasus revenge porn dijerat dengan Pasal 32 UU Pornografi yang berbunyi: "Setiap orang yang memperdengarkan, mempertontonkan, memanfaatkan, memiliki, atau menyimpan produk pornografi sebagaimana dimaksud dalam Pasal 6 dipidana dengan pidana penjara paling lama 4 (empat) tahun dan/atau pidana denda paling banyak Rp2.000.000.000,00 (dua miliar rupiah)."

Revenge porn merupakan suatu tindak pidana yang pendistribusiannya dilakukan dalam bentuk media/data elektronik. Sebagaimana diatur dalam Pasal 27 UU Pornografi, data elektronik yang berkaitan dengan kasus revenge porn dapat dijadikan alat bukti, serta dapat dihapus atau dimusnahkan dari media sosial yang merupakan ranah publik. Apabila merujuk pada Pasal 27 ayat (1) UU ITE yang berbunyi "Setiap orang dengan sengaja dan tanpa hak mendistribusikan dan/atau mentransmisikan dan/atau membuat dapat diaksesnya Informasi Elektronik dan/atau Dokumen Elektronik yang memiliki muatan yang melanggar kesusilaan", dapat dilihat bahwa isi pasal tersebut telah memenuhi seluruh unsur-unsur pidana dalam tindakan revenge porn. Oleh karena itu, hingga saat ini, Pasal 27 ayat (1) UU ITE merupakan salah satu dasar hukum yang dapat dikenakan bagi pelaku tindak pidana revenge porn di Indonesia (Willihardi, 2020).

Namun, bunyi Pasal 27 ayat (1) UU ITE telah menimbulkan banyaknya kontroversi di masyarakat. Kontroversi ini diakibatkan oleh penggunaan kata "melanggar kesusilaan" dalam bunyi pasal tersebut, mengingat bahwa UU ITE sendiri tidak memberikan penjelasan secara rinci mengenai istilah"melanggar kesusilaan" tersebut. Nilai kesusilaan memiliki cakupan yang sangat luas tergantung dari waktu serta kondisi saat terjadinya suatu perbuatan, sedangkan Pasal 27 ayat (1) UU ITE tidak memberikan batasan yang jelas (Adilah, 2021). Hal inilah yang mengakibatkan bunyi pasal ini bersifat multitafsir sehingga banyak masyarakat menyebutnya sebagai 'pasal karet' (Saeno, 2021). Kerancuan yang terdapat pada bunyi Pasal 27 ayat (1) UU ITE menjadikan pasal tersebut tidak cukup baik untuk dijadikan acuan dan dasar hukum dalam menangani kasus revenge porn.

RUU PKS hingga saat ini belum kunjung disahkan, padahal RUU PKS telah masuk dalam Program Legislasi Nasional (Prolegnas) sejak tahun 2016 dan seharusnya menjadi prioritas. Banyak masyarakat yang menganggap Dewan Perwakilan Rakyat (DPR) tidak serius menanggapi permasalahan serta kasus kekerasan seksual yang marak terjadi di Indonesia. Selain itu, banyak sekali pro dan kontra yang ditimbulkan dari eksistensi RUU PKS.

Tidak sedikit masyarakat yang mengkritisi substansi dari RUU PKS serta menolak pengesahan RUU PKS dengan alasan-alasan sebagai berikut (Tamam, 2019): 1) RUU PKS dapat melegalkan praktek-praktek menyimpang kaum Lesbian, Gay, Bisexual, Transgender (LGBT) serta mengkriminalisasi orang yang mengkritik perilaku LGBT; 2) Pasal 12 RUU PKS dapat mengkriminalisasi orang yang mengkritik kebebasan berbusana, dengan contoh kasus yaitu orang tua dapat dipidanakan dengan pasal yang tercantum dalam RUU PKS apabila memaksa anaknya menggunakan hijab; 3.) Pasal 17 RUU PKS dianggap dapat mengkriminalisasi orang 
yang dianggap 'memaksa' menikah, dengan contoh kasus yaitu orang tua dapat dipidanakan dengan pasal yang tercantum dalam RUU PKS apabila mencoba memaksa menikahkan anaknya. Hal ini dianggap bertentangan dengan kearifan budaya timur dalam relasi antar orang tua dan anak, yang menganggap bahwa memaksa menikahkan anaknya merupakan permintaan/harapan orang tua demi kebaikan sang anak (Mohsi, 2020); 4.) Pasal 18 RUU PKS dianggap dapat dijadikan justifikasi untuk melakukan seks bebas, perzinahan, serta pelacuran; 5.) Pengesahan RUU PKS dianggap menyediakan alat kontrasepsi secara bebas kepada pasangan remaja yang belum memiliki ikatan sebagai suami istri, serta menyediakan alat kontrasepsi bagi pasangan LGBT; 6.) RUU PKS dianggap bertentangan dengan UU Penghapusan Kekerasan Dalam Rumah Tangga (UU PKDRT), UU Perkawinan, UU Perlindungan Anak, dan Hukum Islam; 7.) RUU PKS dianggap bertentangan dengan normanorma agama dan tidak berlandaskan ideologi Pancasila (Nurrahman, 2019); 8.) Kitab UndangUndang Hukum Pidana (KUHP) sudah cukup untuk dijadikan dasar hukum dalam menangani kasus kekerasan seksual, sehingga RUU PKS tidak dibutuhkan; 9.) RUU PKS dianggap sebagai peraturan ambigu yang diangkut dari paham feminis liberal dan bertentangan dengan ideologi bangsa Indonesia (Ibrahim, 2019); 10.) Judul RUU PKS dianggap memiliki definisi yang ambigu dan buram; 11.) Tim penyusun RUU PKS tidak mencantumkan asas-asas agama dalam penyusunan RUU PKS, dan substansi dari RUU PKS tidak berjalan sesuai dengan syariat Islam; 12.) Dan lain-lain.

Selain itu, Pasal 45 ayat (1) RUU PKS mengatur bahwa keterangan yang diberikan oleh korban sudah cukup untuk dijadikan alat bukti apabila disertai dengan satu alat bukti lainnya, dimana alat bukti tersebut meliputi: “a.) surat keterangan psikolog dan/atau psikiater; b.) rekam medis dan/atau hasil pemeriksaan forensik; c.) rekaman pemeriksaan dalam proses penyidikan; d.) informasi yang diucapkan, dikirim, diterima atau disimpan secara elektronik dengan alat optik atau yang serupa dengan itu; e.) dokumen; dan f.) hasil pemeriksaan rekening bank."

Pasal tersebut telah bertetangan dengan Pasal 184 ayat (1) Kitab Undang-undang Hukum Acara Pidana (KUHAP) yang menyatakan bahwa bukti permulaan membutuhkan minimal dua alat bukti berupa “a.) keterangan saksi; b.) keterangan ahli; c.) surat; d.) petunjuk; dan e.) keterangan terdakwa." Alasan dibutuhkannya minimal 2 alat bukti serta pemeriksaan calon tersangka dalam proses peradilan hukum pidana adalah untuk transparansi dan perlindungan hak asasi seseorang agar sebelum seseorang ditetapkan sebagai tersangka telah dapat memberikan keterangan secara seimbang (Pramesti, 2017). Pembuktian yang diatur dalam RUU PKS memudahkan korban, namun di sisi lain juga tidak mengedepankan hak asasi yang dimiliki oleh pelaku, mengingat bahwa terdapat asas praduga tak bersalah dalam sistem hukum pidana di Indonesia.

Terdapat upaya preventif dan represif yang dapat dilakukan guna menanggulangi kasus revenge porn di Indonesia. Yang dimaksud dengan langkah preventif adalah pencegahan sebelum terjadinya suatu tindak kejahatan, hal ini dapat dilakukan dengan cara mengedukasi masyarakat mengenai kekerasan seksual, meningkatkan kesadaran masyarakat terkait maraknya KBGO yang terjadi di Indonesia, serta mengajak masyarakat untuk tidak melakukan dan melawan segala bentuk tindak kekerasan seksual.

Sedangkan yang dimaksud dengan langkah represif adalah penyelesaian dan tindak lanjut setelah terjadinya suatu tindak kejahatan. Hal ini dapat dilakukan dengan cara memperkuat sistem hukum pidana di Indonesia, membuat regulasi yang secara spesifik 
Jurnal Yustika

Vol. 24 No. 01, Juli 2021

Halaman | 57 Urgensi Pengesahan RUU PKS sebagai Upaya Perlindungan Hukum Bagi Korban Revenge Porn

Cindy Kang mengatur mengenai tindak kejahatan kekerasan seksual serta memberikan sanksi yang setimpal kepada pelaku kekerasan seksual.

\subsection{Perlindungan Hukum bagi Korban Revenge Porn di Indonesia}

Terlepas dari banyaknya kontra serta penolakan masyarakat mengenai pengesahan RUU PKS, terdapat banyak sekali alasan mengapa RUU PKS harus segera disahkan. Mengingat bahwa perempuan merupakan salah satu sasaran empuk dalam tindak kekerasan seksual, dibutuhkan adanya jaminan perlindungan bagi kaum perempuan. Penting sekali untuk melindungi serta menjamin pemenuhan hak-hak perempuan yaitu hak kemerdekaan, kesetaraan dan integritas, hak atas kesetaraan hukum, hak atas politik dan demokrasi, hak untuk mendapatkan pendidikan, hak untuk mendapat pekerjaan, hak ekonomi, hak untuk bereproduksi maupun tidak bereproduksi, hak untuk melakukan perkawinan dan berkeluarga, serta hak-hak lainnya (Subarkah \& Tobroni, 2021).

KUHP di Indonesia tidak mengatur secara khusus mengenai bentuk-bentuk kekerasan seksual. Tindak pidana kekerasan seksual yang diatur dalam KUHP hanyalah tindak pidana pemerkosaan. Hal inilah yang menyebabkan dibutuhkannya pengesahan RUU PKS guna melengkapi dan menyempurnakan regulasi di KUHP dan menjadi lex spesialis dalam menangani kasus kekerasan seksual di Indonesia. Pasal 11 ayat (2) RUU PKS dengan rinci menegaskan bahwa terdapat sembilan bentuk kekerasan seksual, yaitu: "a) pelecehan seksual; b) eksploitasi seksual; c) pemaksaan kontrasepsi; d) pemaksaan aborsi; e) pemaksaan perkawinan; f) pemerkosaan; g) pemaksaan pelacuran; h) perbudakan seksual; dan i.) penyiksaan seksual (Subarkah \& Tobroni, 2021).

Adanya RUU PKS dapat menciptakan prosedur dan sistem pembuktian yang lebih berpihak pada korban. Korban kekerasan seksual, khususnya korban revenge porn, tentu mengalami sejumlah kerugian, seperti mendapat stigma negatif, mengalami kerusakan relasi sosial hingga trauma psikologis. Pasal 28 RUU PKS secara rinci mengatur mengenai hak korban untuk mendapatkan pemulihan sebelum dan selama proses peradilan berlangsung. Selain itu, mengacu pada Pasal 40 RUU PKS, korban kekerasan seksual berhak mendapatkan pendampingan dari berbagai pihak seperti tenaga kesehatan, pendampingan psikologis, serta pendampingan hukum. Seringkali aparat penegak hukum tidak memiliki memandang suatu hal dari perspektif korban, eksistensi dari RUU PKS yang berperspektif korban akan sangat membantu korban dalam memperoleh hak-haknya (Adinda, 2019). Selain itu, kasus kekerasan pada umumnya mengalami hambatan dan kesulitan akibat kurangnya alat bukti, adanya Pasal 45 pada RUU PKS secara rinci menjabarkan bahwa selain menerapkan prosedur pembuktian yang berlaku pada KUHAP, terdapat alat bukti lain yang berperspektif korban.

Merupakan kewajiban dari negara untuk melindungi dan memenuhi hak-hak korban kekerasan seksual serta memberikan pelayanan hukum yang terpadu dan terintegrasi. Tidak adanya perlindungan bagi korban akan menyebabkan korban kesulitan saat menuntut hakhaknya. Berdasarkan survei dari Thorn and the Crimes Against Children Research Center, hanya $17 \%$ dari korban yang memiliki keberanian untuk melaporkan kekerasan seksual kepada aparat 
penegak hukum (Christian, 2020). LBH APIK menyatakan bahwa korban revenge porn merasa takut mendapat stigma dari masyarakat sehingga tidak melaporkan kasusnya kepada aparat kepolisian. Selain itu, hanya $2 \%$ dari keseluruhan laporan kasus revenge porn yang ditindak hingga tahap persidangan akibat tidak diproses lebih lanjut oleh aparat kepolisian (Willihardi, 2020).

Angka pelaporan yang sangat rendah diakibatkan karena rasa takut dan malu yang dialami korban, serta tekanan dari masyarakat yang masih kental dengan budaya victim blaming atau menyalahkan korban. Berkembangnya budaya victim blaming di Indonesia dapat mengakibatkan tekanan psikis bagi korban. Begitu banyak permasalahan yang ditimbulkan oleh kekerasan seksual, sehingga berdasarkan yang tercantum pada Pasal 3 RUU PKS menyatakan bahwa "Penghapusan Kekerasan Seksual bertujuan untuk a.) mencegah segala bentuk kekerasan seksual; b.) menangani, melindungi, dan memulihkan korban; c.) menindak pelaku; dan d.) mewujudkan lingkungan bebas kekerasan seksual".

Penolakan pengesahan RUU PKS dengan argumen bahwa RUU PKS melegalkan perzinahan, mengkriminalisasikan kawin paksa, mengkriminalisasikan kritik terhadap kebebasan berbusana, serta argumen-argumen lainnya merupakan hal yang tidak benar. RUU PKS menjunjung kebebasan individu tanpa memaksakan kehendak orang lain. RUU PKS berpedoman dan berlandaskan konsep hak asasi manusia bahwa setiap orang memiliki kedudukan yang sama tanpa memandang gender. Terjadinya kasus kekerasan seksual yang sulit dalam hal pembuktian akan mengakibatkan korban tidak mendapat keadilan.

Sebagaimana tercantum dalam Pasal 22 RUU PKS, korban berhak atas penanganan, perlindungan, serta pemulihan, dan hal tersebut merupakan tanggung jawab negara. Namun, regulasi yang selama ini sudah ada di Indonesia hanya berfokus menindaklanjuti pelaku dan tidak berfokus memberikan perlindungan bagi korban (Yulia, 2016). Substansi serta prosedur penyelesaian perkara tindak kejahatan revenge porn maupun kekerasan seksual lainnya tidak memberikan manfaat yang signifikan bagi pemulihan korban (Perangin-angin, Rahayu \& Dwiwarno, 2019). Perlu diingat bahwa korban sangat dirugikan baik dari reputasi di lingkungan sosial hingga ke tekanan psikologis (Ramailis, 2020). Jika dilihat dari perspektif hukum pidana, KUHP dan KUHAP tidak menjabarkan terkait kedudukan korban dan hak korban. Penyidik atau penuntut umum cenderung memposisikan korban sebagai saksi yang menunjang berjalannya proses peradilan dan tidak memperhatikan hak-hak korban.

United Nation Secretary-General Guidance Note on Reparations for Conflict-Related Sexual Violence menegaskan bahwa penanganan kekerasan seksual selama ini belum memprioritaskan pemulihan korban. Pemulihan korban dapat terdiri atas beberapa tindakan yaitu memberikan restitusi, kompensasi, rehabilitasi, serta menjamin bahwa tindakan tersebut tidak akan terulang kembali. Terdapat beberapa permasalahan terkait regulasi yang mengatur mengenai korban kekerasan seksual di Indonesia, yaitu sebagai berikut (Eddyono \& Rahmawati, 2017):

Pertama, UU PKDRT mengatur mengenai pelaporan kasus oleh korban, yang membuat korban dapat secara tidak langsung melaporkan kasus kekerasan yang dialaminya. Regulasi dalam UU PKDRT membuat korban dapat melapor dengan diwakili oleh kuasanya. Namun 
Jurnal Yustika

Vol. 24 No. 01, Juli 2021

Halaman I 59

Urgensi Pengesahan RUU PKS sebagai Upaya Perlindungan Hukum Bagi Korban Revenge Porn

Cindy Kang regulasi ini hanya diterapkan pada UU PKDRT saja. Oleh karena itu, dibutuhkan mekanisme pelaporan kekerasan seksual yang berfokus memberikan kemudahan pada korban serta melibatkan pihak lain seperti kepolisian, rumah sakit, maupun lembaga-lembaga lain yang dapat mendampingi korban. Kedua, korban berhak untuk dirahasiakan identitasnya, namun berkaca pada keadaan di lapangan, hal ini tidak diimplementasikan dengan baik. Terdapat beberapa putusan pengadilan yang memuat identitas korban secara rinci. Hal ini juga berlaku sama pada media-media pemberitaan yang menyudutkan korban. Ketiga, korban berhak mendapatkan pendampingan serta bantuan hukum, namun dalam beberapa kasus hal ini tidak diimplementasikan dengan baik. Korban pemerkosaan yang masih berusia di bawah umur melakukan tindakan bunuh diri setelah melaporkan pemerkosaan tersebut. Hal ini tidak akan terjadi apabila korban diberikan pendampingan serta layanan pemulihan yang layak; Keempat, Korban berhak untuk tidak dituntut secara perdata maupun pidana atas keterangan dan laporan yang ia berikan, namun berkaca pada keadaan di lapangan, masih banyak korban kekerasan seksual yang justru dikriminalisasi oleh pelaku; Kelima, KUHAP serta UU Perlindungan Saksi dan Korban mengatur bahwa korban berhak mendapat biaya transportasi, namun berkaca pada fakta di lapangan, banyak kasus kekerasan seksual yang proses hukumnya diberhentikan akibat kekurangan biaya; Keenam, UU ITE mengatur bahwa korban berhak mendapatkan hak untuk dilupakan. Hal ini sangat bermanfaat mengingat terancamnya reputasi korban revenge porn yang foto-foto pribadinya tersebar di media maya. Namun, berkaca pada fakta di lapangan, proses penghapusan informasi membutuhkan waktu yang sangat lama. Dengan proses yang sangat lambat, hal itu menyebabkan konten pornografi tersebut terlanjut tersebar luas (Christianto, 2020).

Penjabaran diatas telah cukup menunjukkan bahwa meskipun terdapat regulasi-regulasi yang mengatur mengenai hak korban kekerasan seksual, namun hal tersebut masih belum cukup memberikan perlindungan serta memenuhi hak-hak korban kekerasan seksual, terutama korban revenge porn. Oleh karena itu, dibutuhkan suatu regulasi khusus yang mengatur secara lengkap dan rinci mengenai kekerasan seksual, penanganan kasus kekerasan seksual, serta hakhak korban kekerasan seksual. Regulasi yang terdapat pada RUU PKS berfokus dan menekankan pada pemenuhan hak-hak korban, serta menjamin bahwa biaya yang dikeluarkan selama pelaporan dan pemulihan akan ditanggung oleh negara.

Selain itu, substansi RUU PKS juga menjamin bahwa sistem peradilan akan berorientasi pada korban, menjamin kerahasiaan identitas korban, menjamin bahwa korban akan dilindungi dari viktimisasi, stigma, serta balas dendam, serta jaminan-jaminan lainnya. Permasalahan balas dendam merupakan salah satu permasalahan utama yang sering dialami oleh keluarga korban kekerasan seksual. Sering sekali keluarga korban mendapatkan ancaman untuk bungkam dan tidak memberi kesaksian. Oleh karena itu, adanya RUU PKS tidak hanya melindungi korban kekerasan seksual, namun juga melindungi keluarga korban serta saksi yang terlibat dalam kasus kekerasan seksual (Amnesty International, 2020). Hal ini menunjukkan bahwa RUU PKS sangat dibutuhkan guna meminimalisir angka kekerasan seksual serta memenuhi kebutuhan korban kekerasan seksual di Indonesia. 


\section{Kesimpulan}

Kasus kekerasan seksual di Indonesia sangat marak terjadi, dan wanita merupakan salah satu korban yang sangat rentan. Selain itu, perkembangan teknologi yang semakin pesat membuat kekerasan seksual dapat terjadi secara daring, salah satu yang paling banyak terjadi adalah revenge porn. Revenge Porn merupakan suatu ancaman terhadap seseorang untuk menyebarkan konten pornografi milik pribadi ke dunia maya tanpa sepengetahuan atau persetujuan orang tersebut, atau dibuat tanpa sepengetahuan orang tersebut. Korban revenge porn dapat mengalami banyak sekali kerugian, dan mengalami kesulitan dalam mendapat perlindungan hukum. Regulasi yang terdapat di Indonesia dinilai tidak cukup memberikan perlindungan hukum serta pemenuhan hak-hak yang dimiliki oleh korban revenge porn maupun korban kekerasan seksual lainnya. KUHP hanya mengatur mengenai tindak pidana pemerkosaan.

Belum ada UU maupun regulasi lainnya di Indonesia yang mengidentifikasi jenis-jenis kekerasan seksual secara spesifik. Oleh karena itu, RUU PKS sangat dibutuhkan guna menjamin terpenuhinya hak-hak korban, dengan menanamkan bahwa merupakan tanggung jawab negara untuk melindungi korban kekerasan seksual. RUU PKS telah menimbulkan banyak pro dan kontra di masyarakat, namun terlepas dari kontra serta penolakan yang diargumentasikan oleh berbagai pihak, kelebihan yang dimiliki oleh RUU PKS tetap sangat dibutuhkan mengingat bahwa kasus kekerasan seksual di Indonesia semakin meningkat, serta mayoritas korban kekerasan seksual merupakan anak perempuan.

\section{Daftar Referensi}

Buku:

Rahmawati, Maidina \& Eddyono, Widodo Supriyadi. (2017). Menuju Penguatan Hak Korban dalam RUU Penghapusan Kekerasan Seksual. Jakarta: Institute for Criminal Justice Reform.

\section{Artikel Jurnal:}

Ananda, N. N. P. T., Praviyanti, N. N., \& Mertha, I. K. (2020). Perlindungan Hukum Terhadap Perempuan Sebagai Korban Pada Tindak Pidana Balas Dendam Pornografi (Revenge Porn). Jurnal Kertha Wicara, 9(4).

Christian, J. H. (2020). Sekstorsi: Kekerasan Berbasis Gender Online Dalam Paradigma Hukum Indonesia. Binamulia Hukum, 9(1), 83-92.

Christianto, H. (2020). Konsep Hak Untuk Dilupakan Sebagai Pemenuhan Hak Korban Revenge Porn Berdasarkan Pasal 26 Undang-Undang Informasi Dan Transaksi Elektronik. Mimbar Hukum: Jurnal Berkala Fakultas Hukum Universitas Gadjah Mada, 32(2), 175-192.

Israpil, I. (2017). Budaya Patriarki Dan Kekerasan Terhadap Perempuan (Sejarah Dan Perkembangannya). PUSAKA, 5(2), 141-150.

Mohsi, M. (2020). Analisis Perkawinan Paksa Sebagai Tindak Pidana Kekerasan Seksual Dalam Rancangan Undang-Undang Penghapusan Kekerasan Seksual PKS. Al-Adalah: Jurnal Hukum dan Politik Islam, 5(1), 1-19.

Nurrahman, A. (2019). Menimbang Semangat Pancasila Dalam Rancangan Undang-Undang Penghapusan Kekerasan Seksual (RUU P-KS). Jurnal Kebijakan Pemerintahan, 13-19.

\section{Jurnal Yustika \\ Halaman | 60 \\ Urgensi Pengesahan \\ RUU PKS sebagai Upaya \\ Perlindungan hukum Bagi \\ Korban Revenge \\ Porn}

Cindy Kang 
Perangin-angin, I. I. P., Rahayu, R., \& Dwiwarno, N. (2019). Kewajiban Dan Tanggungjawab Negara Memberikan Perlindungan Hukum Terhadap Perempuan Korban Revenge Porn Di Indonesia. Diponegoro Law Journal, 8(1), 457-483.

Jurnal Yustika

Vol. 24 No. 01, Juli 2021

Halaman | 61

Urgensi Pengesahan RUU PKS sebagai

Upaya

Perlindungan

Hukum Bagi

Korban Revenge

Porn

Cindy Kang
Rais, N. F., Manurung, G. P., \& Wardani, A. K. (2019). Analisis Keberlakuan RKUHP dan RUUPKS dalam Mengatur Tindak Kekerasan Seksual. Lex Scientia Law Review, 3(1), 55-68.

Ramailis, N. W. (2020). Cyber Crime Dan Potensi Munculnya Viktimisasi Perempuan Di Era Teknologi Industri 4.0. Sisi Lain Realita, 5(01), 1-20.

Siburian, R. J. (2020). Marital Rape Sebagai Tindak Pidana dalam RUU-Penghapusan Kekerasan Seksual. Jurnal Yuridis Vol, 7(1), 149-169.

Subarkah, A. A. J., \& Tobroni, F. (2021). Urgensi Pengesahan RUU PKS Terhadap Instrumen Penegakan Hak Asasi Perempuan. Supremasi Hukum: Jurnal Kajian Ilmu Hukum, 9(2), 90115.

Tamam, A. B. (2019). Rancangan Undang-Undang Penghapusan Kekerasan Seksual (RUU PKS) dalam Perspektif Maslahah Mursalah. In Proceedings of Annual Conference for Muslim Scholars 3(1), 848-856.

Willihardi, A. P. (2020). Analisis Yuridis Perlindungan Hukum bagi Korban Penyebarluasan Konten Pornografi Dengan Motif Balas Dendam (Revenge Porn) di Indonesia (Doctoral dissertation, UPN Veteran Jawa Timur).

Yulia, Rena. (2016). Mengkaji Kembali Posisi Korban Kejahatan Dalam Sistem Peradilan Pidana. Mimbar Hukum: Fakultas Hukum Universitas Gadjah Mada, 28(1), 33-45.

Artikel Internet:

Adilah, Rifa Yusya. (2021). ICJR Soroti Pasal UU ITE Tentang Melanggar Kesusilaan. Available online from: https://www.merdeka.com/peristiwa/icjr-soroti-pasal-uu-ite-tentang-melanggarkesusilaan.html . [Accessed June 24, 2021].

Adinda, Permata. (2019). Derita Korban Revenge Porn: Trauma hingga Tak Mendapat Perlindungan Hukum. Available online from: https://asumsi.co/post/3852/derita-korbanrevenge-porn-dari-trauma-hingga-minimnya-perlindungan-hukum . [Accessed 29 September 2021].

Amnesty International. (2020). Empat Urgensi Pengesahan RUU PKS. Available online from: https://www.amnesty.id/empat-urgensi-pengesahan-ruu-pks/. [Accessed July 11, 2021].

Arifin, Difa. (2019). Mengapa Rape Culture Tumbuh Subur di Indonesia?. Available online from: www.suarasikap.com/2019/01/mengapa-rape-culture-tumbuh-subur-di.html. [Accessed June 22, 2021].

Azizi, Ismail A. (2020). Mengenal untuk Tidak Menjadi Korban dan Tersangka Revenge Porn. Available online from: https://suakaonline.com/mengenal-untuk-tidak-menjadi-korban-dantersangka-revenge-porn/. [Accessed July 11, 2021].

Febrianna, Alfida \& Ayu, Nadia. (2021). Kasus Jual Beli Revenge Porn, Korban Dieksploitasi dan Belum Terlindungi Hukum. Available online from: https://ketik.unpad.ac.id/posts/3011/kasus-jual-beli-revenge-porn-korban-dieksploitasi-dan-belumterlindungi-hukum. [Accessed July 11, 2021].

Ibrahim, Gibran Maulana. (2019). Ini Sederet Alasan F-PKS Tolak RUU Penghapusan Kekerasan Seksual. Available online from: https://news.detik.com/berita/d-4417286/ini-sederet-alasan-fpks-tolak-ruu-penghapusan-kekerasan-seksual . [Accessed June 26, 2021].

Ika, Wijatnika. (2019). Kasus Baiq Nuril, Bukti Indonesia Darurat Kekerasan Seksual. Available online from: https://www.kompasiana.com/wijatnikaika/5d2325b50d82300af03db843/kasus-baiqnuril-bukti-indonesia-darurat-kekerasan-seksual?page=all. [Accessed June 20, 2021].

Kementerian Pemberdayaan Perempuan dan Perlindungan Anak. (2020). Dorong RUU PKS, Wujudkan Aturan Terkait Kekerasan Seksual Berperspektif Korban. Available online from: $\quad$ https://www.kemenpppa.go.id/index.php/page/read/29/2818/dorong-ruu-pks-wujudkanaturan-terkait-kekerasan-seksual-berperspektif-korban. [Accessed September 27, 2021]. 
LM Psikologi UGM. (2021). Satu Tahun Pandemi: Meningkatnya Kekerasan Basis Gender Online. Available online from: https://m.psikologi.ugm.ac.id/2021/03/satu-tahun-pandemimeningkatnya-kekerasan-basis-gender-online/ . [Accessed June 21, 2021].

Oktaviani, Eti. (2020). Mengenali Revenge Porn, Salah Satu bentuk Kekerasan Seksual Melalui Dunia Maya. Available online from www.lbhsemarang.id/news/mengenali-revenge-pornsalah-satu-bentuk-kekerasan-seksual-melalui-dunia-maya41925. [Accessed June 23, 2021].

Pramesti, Tri Jata Ayu. (2017). Arti "Bukti Permulaan yang Cukup" dalam Hukum Acara Pidana. Available online from: https://hukumonline.com/klinik/detail/ulasan/lt5940eb061eb61/arti-bukti-permulaan-yang-cukupdalam-hukum-acara-pidana/ . [Accessed July 11, 2020].

Riana, F., \& Amirullah. (2021). Komnas Perempuan: Ada 299.911 Kasus Kekerasan terhadap Perempuan 2020. Available online from: https://nasional.tempo.co/read/1439271/komnas-perempuan-ada-299-911-kasus-kekerasanterhadap-perempuan-sepanjang-2020 . [Accessed June 20, 2021].

Saeno. (2021). Pasal Karet UU ITE: Penerapan Pasal 27 Dinilai Tidak Merujuk ke KUHP. Available online from: https://kabar24.bisnis.com/read/20210320/16/1370165/pasal-karet-uuite-penerapan-pasal-27-dinilai-tidak-merujuk-ke-kuhp . [Accessed June 25, 2021].

Safenet Voice. (2020). Rilis Pers: Peningkatan Kekerasan Berbasis Gender Online selama Pandemi. Available online from: https://id.safenet.or.id/2020/12/rilis-pers-peningkatankekerasan-berbasis-gender-online-selama-pandemi/. [Accessed June 23, 2021].

The Conversation. (2020). Kekerasan Seksual Di Internet Meningkat Selama Pandemi Dan Sasar Anak Muda: Kenali Bentuknya Dan Apa Yang Bisa Dilakukan?. Available online from: https://theconversation.com/kekerasan-seksual-di-internet-meningkat-selama-pandemi-dan-sasaranak-muda-kenali-bentuknya-dan-apa-yang-bisa-dilakukan-152230, [Accessed June 23, 2021].

Voi. (2020). Konten Porno Marak di Medsos, Ahli Hukum: Perlindungan Korban Harus Jadi yang Utama. Available online from https://voi.id/berita/19299/konten-porno-marakdi-medsos-ahli-hukum-perlindungan-korban-harus-jadi-yang-utama . [Accessed July 11, 2021].

Yayasan Pulih. (2020). Humor Seksis? Please Jangan Dilakuin!. Available online from: http: https://yayasanpulih.org/2020/07/humor-seksis-please-jangan-dilakuin/. [Accessed June 20, 2021]. 